\title{
The effect of digital technology development on economic growth
}

\section{Inna Irtyshcheva ${ }^{\text {a }}$, Marianna Stehnei ${ }^{\text {b }}$, Nazariy Popadynets ${ }^{c^{*}}$, Konstantin Bogatyrev ${ }^{\mathrm{d}}$, Yevheniia Boiko $^{a}$, Iryna Kramarenko ${ }^{\mathrm{e}}$, Oleksandr Senkevich ${ }^{\mathrm{a}}$, Nataliya Hryshyna ${ }^{\mathrm{a}}$, Ivanna Kozak ${ }^{\mathrm{f}}$ and Olena Ishchenko ${ }^{a}$}

${ }^{a}$ National University of Shipbuilding named after Admiral Makarov, Ukraine

${ }^{b}$ Mukachevo State University, Ukraine

"SI "Institute of Regional Research named after M. I. Dolishniy of the NAS of Ukraine", Ukraine

${ }^{d}$ South Ukrainian National Pedagogical University, named after K.D. Ushinsky, Ukraine

${ }^{e}$ Mykolaiv Interregional Institute of Human Development of the University "Ukraine", Ukraine

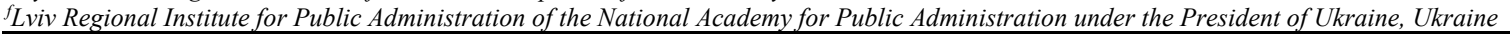

\section{CHRON I C L E}

Article history:

Received: September 9, 2020

Received in revised format: Sep-

tember 9, 2020

Accepted: November 6, 2020

Available online: November 6 , 2020

Keywords:

Digital Technologies

Digitalization

Economic Growth

Modelling

Trends

\section{A B S T R A C T}

\begin{abstract}
The article simulates the impact of the digital technologies' development on economic growth, which makes it possible to find ways to improve the quality of various spheres of life and identify areas of the economy, the accelerated digitalization of which will ensure an increase in gross domestic product (GDP). The research used groupings of economic activities that directly influence the development of the digital economy. Using the data of regression models, the coefficients of GDP elasticity from the development of the studied sectors were calculated and used to forecast GDP under the development influence of the studied sectors while maintaining the existing trends. The dynamics of the e-commerce market development in Ukraine, the dynamics of production volumes of products (services) of the main types of economic activities in the field of digital transformation of the economy in Ukraine, the dynamics of financial results of enterprises in the information and telecommunications sector in Ukraine, the dynamics of capital investments in the field of information and communications of Ukraine, the dynamics of foreign investment in the development of the type of economic activity "information and telecommunications" in Ukraine, the dynamics of the development of the main areas of digitalization of the Ukrainian economy in 2010-2018 and the dynamics of GDP in actual prices were revealed. A correlation and regression analysis of the impact of the main indicators of the digital technologies sectors development on Ukraine's GDP is also carried out. The forecast extrapolation trend of production growth volumes of products and services in the information sector of Ukraine was built. A forecast of GDP growth in Ukraine has been constructed, taking into account the processes of digitalization of the economy in accordance with certain trends. The forecast dynamics of changes in GDP under the influence of the IT sector development until 2023 was also illustrated. It was found that Ukraine lags significantly behind most developed countries in terms of the level of industrial production development of information and communication technologies and equipment, Ukraine is completely import-dependent in this area. It has been proved that stimulating the development of information and communication technologies has significant prospects for activating digitalization processes in all spheres of the economy and society and increasing GDP.
\end{abstract}

\section{Introduction}

The development of relationships in a social environment depends on the level of economic development. This applies to any level: global, European, national, regional, territorial, etc. The digitalization of the economy is a specific economic technology with its own characteristics, trends and patterns. Many countries of the world use this technology to improve the efficiency of economic development, increase competitiveness, and etc.

* Corresponding author

E-mail address: popadynets.n@gmail.com (N. Popadynets) 
The results of the digital economy are the same products as in ordinary economic activity. Thus, the digital economy is not a separate industry, but simply acts as a virtual addition to the real traditional economy. The digitalization of society provides for the formation of relationships between government, business and society using the latest information technologies, covers socio-economic events on the Internet platform, mobile and sensor networks. The digital economy is based on the ability to access the Internet. The introduction of the digital economy makes it possible to increase labor productivity, business competitiveness and the well-being of citizens. To implement the digital economy, first of all, it is necessary to provide expanded access to the Internet, because today the Internet is the most important element of economic development.

The current stage of socio-economic systems development is characterized by rapid structural and qualitative transformations under the influence of the rapid spread of innovative technologies, including digital technologies. The processes of digitalization of the economy and social relations contribute to the deepening of interaction between all subjects of the market environment that go beyond national borders, create the preconditions for GDP growth, increase labor productivity, introduce and spread innovations in all spheres of life. At the same time, rapid technological changes that have a multiplier effect require the formation of qualitatively new, adaptive approaches and models for managing economic processes at all levels. Without taking into account the influence of the main trends in the digitalization of society on the development of economic and social processes, the formation of strategies for the economic development of the state, regions and individual industries has no practical meaning. The digital economy is based on the introduction and widespread use of technologies for storing and processing large amounts of information (Big data, cloud computing), the Internet of Things, end-to-end information technologies, cyber security technologies, robotization and comprehensive automation of most processes and industries and other areas of development of innovative technologies that change the human role in the economic system.

In Ukraine, the development of the digital economy is just beginning, we have lost several years due to the lack of a purposeful state policy towards the digitalization of the economy. All EU countries have their own "digital strategies" or "digital agendas", but in Ukraine it remained at the development stage, that is, in the form of an unapproved project "Digital Agenda 2020", which states, that "Ukrainian politicians, central and local authorities, public organizations and business should assume their historical responsibility for supporting and actively promoting the country's development in this direction. Our policy in the field of "digitalization" puts people at the center of everything, their intelligence, their talent, their natural desire to create. Under certain conditions and joint efforts of the public, government and business, the colossal human potential of Ukraine should become a human capital of global significance and influence. We believe that "digital" technologies are both a huge market and an industry, as well as a platform for the efficiency and competitiveness of all other markets and industries. We share the UN statement on access to the Internet as a fundamental human right, as an open, safe and free space, as a network that disseminates thoughts, ideas, information, knowledge and enables people to communicate and socially interact" (Ucci, 2020). It is difficult to imagine the sphere of human activity without the possibilities of using digital technologies. Business development, healthcare, culture, transport, environmental protection are areas of activity that only improve their development with the use of digital technologies. An important direction for ensuring economic growth is the development of digital technologies, which leads to an increase in efficiency and labor productivity, regardless of the type of activity. It is important to ensure the mutual consistency of individual digitalization programs with regional and national development strategies. Modelling the impact of the digital technologies development on economic growth will make it possible to find ways to improve the quality of various spheres of life.

\section{Literature review}

Features of the development of various economy types, including the digital economy, formed the basis for the research of many domestic and foreign scientists. In particular, the specified features of the development of the digital economy by Tapscott (1996), Stroyko (2013), Vasyltsiv et al. (2020), Voynarenko (2015), Pavlova, (2020), Kit (2014), Yakubiv (2015), Irtyshcheva et al. (2020), Maksymiv (2016), Malyk (2013), Pryshchepa (2020) and Melnyk et al. (2018) studied digital technologies in the development of regional IT clusters, namely the features, trends and priorities of their functioning. Thus, Park (2018) as his article explores digital technologies in the fourth industrial revolution, which can change the global production chain and how mainstream technologies and digital technologies function in various industrial sectors. A number of other scientists believe that it is precisely new technologies, technological innovations in the field of information and communication technologies that are becoming the most important sign of changes in the economic system, while simultaneously acting as a driver of economic development. Thus, the growing scale of technological innovations, especially in the field of communications, can transform the system of socio-economic relations and contribute to the spread of digital technologies (Fuchs, 2008; Mulgan, 1991). Semjachkov (2017) defines the sector for the production of digital products and services related to digital technologies as the core of the digital economy. However, its capabilities have not been determined in the context of the development of transformational processes of territorial-economic systems.

At the same time, the lack of sufficient evidence to prove the impact of digital technology development on economic growth reduces opportunities for improving various spheres of life.

As a hypothesis of our research, the possibility of using elements of modelling the impact of the digital technologies' development on economic growth in the direction of improving various spheres of life is considered. 


\section{Materials and Methods}

Without the possibility of modelling socio-economic phenomena and processes, it is impossible to imagine a modern management system at its various levels. Modelling is used to diagnose the current state and development prospects of management objects, to identify cause-and-effect relationships, to study development trends and mechanisms for the formation of variations in socio-economic phenomena and processes, to identify areas for improving various spheres of life.

The category "modelling" can be understood as the research of real objects of knowledge based on their artificial display using the means of mathematics, statistics and econometrics. Integral indicators, equations, inequalities, graphs and the like should be considered as display means. A feature of assembling models of socio-economic phenomena is the possibility of economic interpretation of modelling results and their use in drawing up plans and forecasts for future periods.

Thus, modelling in the research of the impact of the digital technologies development on economic growth can be considered as one of the means of cognition and identifying areas for improving the spheres of life.

The influence of the digitalization effect is determined by the added value created in each industry under the influence of digital technologies at the macro level, and by the increase in the gross value added of all spheres of economic activity at the macro level.

Considering the new form of presentation of statistical data, used by the State Statistics Service of Ukraine in the framework of the implementation of statistical indicators in accordance with Regulation (EC) No. 251/2009 of 11.03.2009, it is possible to research the main trends in the development of information technologies and their impact on the national economy, in particular growth GDP. According to the new form of grouping, statistical data are submitted on a set of types of economic activities that directly affect the development of the digital economy, namely:

1) Information and communication technologies in production (B), combining types of economic activities are directly engaged in the production of information and communication equipment (production computers and peripheral equipment, communication equipment and other types of electronics, as well as the production of components for these products).

2) Information and communication technologies in services $(P)$, which determine the types of economic activities for the provision of telecommunications services, services for the implementation and installation of software, repair and maintenance of information and communication infrastructure, and etc.

3) Information sector (services using computer equipment) (I), which summarizes the activities of enterprises engaged in direct work with information (digital) systems, namely: development, modification, testing and technical support of software, planning and design of integrated computer systems, integrating hardware, software and communication technologies; management and maintenance of clients' computer systems and/or data processing and other professional activities in the field of information technology (State Statistical Service of Ukraine, 2020).

Regression models of the influence of individual sectors of the digital technologies sphere on Ukraine's GDP in the form of the equation $y=f(x)$ were constructed and verified by using mathematical ones. To determine the closeness of the relationships between real phenomena and processes and their degree of proximity to the functional form, the determination coefficient $\mathrm{R}^{2}$ was calculated. The models were verified by Fisher's F-test and the statistical significance of the models was shown.

Using the data of regression models for calculating the elasticity coefficients of GDP from the development of the studied sectors, which can be used to predict GDP under the influence of the development of the studied sectors while maintaining the existing trends.

Forecasting GDP growth under the influence of the forecast growth of individual sectors of the digitalization of the economy was carried out according to the formula:

$$
G D P_{\text {forecast. }}^{t}=G D P_{\mathrm{e}}^{t}+\left(\mathrm{K}_{\mathrm{c}} \times \mathrm{T}_{\mathrm{c}_{\text {forecast. }}}^{t} \times G D P_{\mathrm{e}}^{t}\right)
$$

where, $G D P_{\text {forecast. }}^{t}$ - forecast value of GDP in year $\mathrm{t}$ under the influence of sector development;

$G D P_{\mathrm{e}}^{t}-$ extrapolation forecast value of GDP in period t;

$K_{c}$ - elasticity coefficient of GDP from the development of a particular IT sector;

$\mathrm{T}_{\mathrm{c}_{\text {forecast. }}}^{t}-$ forecast growth rate of the sector in the year $\mathrm{t}, \%$

\section{Results and discussion}

The Ukrainian market of Internet commerce, responding to the constantly growing demand, is developing towards diversification, increase, integration and reduction in cost of online services, while repeating the global trends in the development of the virtual market. This is evidenced by the main trends in the increase in the online commerce market, the volume of which increased by almost 18 times over the period 2012-2019. At the same time, the peak of growth of consumers of e-commerce services (over 207\%) compared to the previous year was observed in 2015. During 2016-2019, there is also an increase, but at a slightly slower pace. 


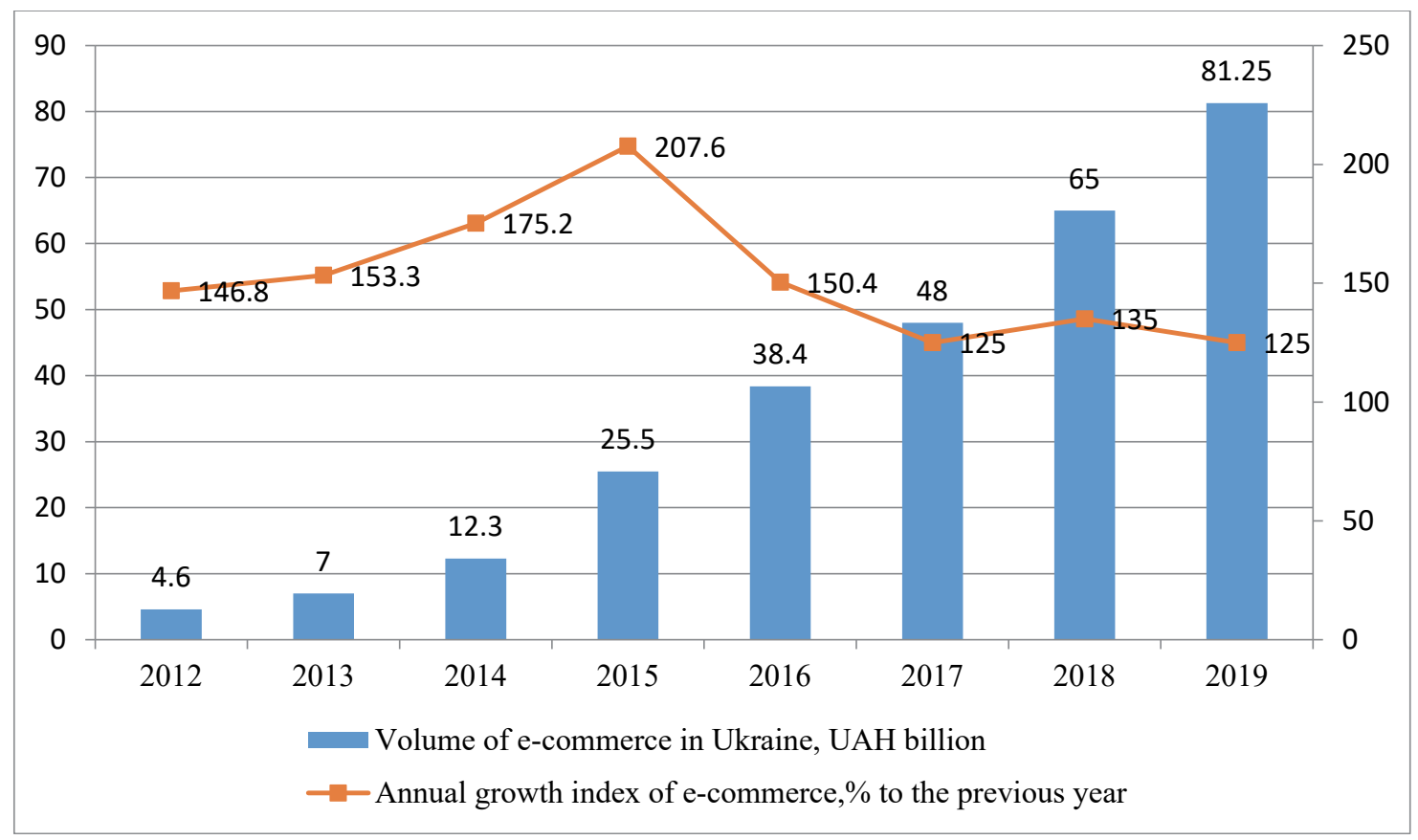

Fig. 1. Dynamics of e-commerce market development in Ukraine

Source: formed according to data (Association of Retailers of Ukraine, 2020)

According to Hlinenko and Daynovskyy (2018) "the growth of e-commerce turnover in Ukraine is obviously due to the fact that for an increasing number of our fellow citizens, the Internet is turning into a natural habitat, within which more and more needs are being satisfied". The authors proved that the growth in the volume of e-commerce in Ukraine is associated with the expansion of citizens' access to the Internet.

The growing role of e-commerce is also due to such factors as:

- saving the consumer's time and choosing products in accordance with the selected filter;

- possibility of considering a wider set of commodity items;

- possibility of choosing goods outside the country.

E-commerce also has a number of advantages (including contactless delivery and the absence of the need to go to crowded places) in an emergency, the device of which can be quarantine associated with the rapid spread of the coronavirus epidemic. In particular, according to a research of the Chinese market, in just a month of quarantine, e-commerce platforms noted more than $200 \%$ growth in demand for food and more than $75 \%$ growth in demand for non-food products. Certain businesses, which worked primarily in contact with consumers, also increased their sales through the Internet platforms created and improved for this purpose. The most successful e-businesses, the volumes of online commerce of which have grown in China during the quarantine period, include: car sales on electronic platforms, delivery of ready-made food and drinks, services for remote work (Microsoft Teams, WeChat Work, and Ding Talk and others), services for online learning, online travel platforms and etc. Also, the outbreak of COVID-19 has led to advancements in the development of artificial intelligence technology that helps brands improve their customer data platforms and data capabilities by combining online and offline data. In addition, the coronavirus outbreak has accelerated the use of $5 \mathrm{G}$ to streamline online shopping and has impacted the accelerated construction of "smart cities". To retain customers, the online direction and the entertainment industry have been strengthened. For instance, the bars ran live DJ sets on the Chinese version of TikTok - the Douyin app. Some broadcast revenues were equivalent to $¥ 2$ million (just over $\$ 280,000$ ) (NVBusiness, 2020).

Taking into account the studies carried out in China can also be extrapolated to the Ukrainian market, since during the quarantine period in Ukraine, the number of Internet users and related services also increased significantly. Considering the new challenges facing modern society, we believe that, subject to the creation of a high-quality information security system and appropriate regulatory support, acceleration of the digitalization of the economy and society at all levels is one of the strategic development tasks of our country.

Despite the fact that Ukraine has not created a proper regulatory framework for the development of the IT sector, under the influence of globalization processes as a reaction to the new requirements of the market environment, the information and telecommunications industry is developing quite rapidly. This is confirmed by statistical data, show the rapid growth in the volume of sales of value-added services by enterprises working in the field of IT technologies. Table 1 shows the development trends of the main components of the digitalization industry of the economy and society in Ukraine according to the current Classification of Types of Economic Activity (CTEA), namely: 
- Telecommunication industry (telecommunications) can be called one of the main infrastructural components of the digitalization of the economy, since it ensures the provision and receipt of communication services between subjects of economic and social processes using public telecommunication networks;

- Computer programming, consulting and related activities directly create a basic product for the transition of the economy to a new level of functioning in the digital world, namely the translation of economic business processes, management processes, economic and social relations into the language of digital technologies;

- Provision of information services is one of the main service parts, connects subscribers, systems and processes, taking into account individual and specific requests and needs.

During the period 2013-2018, there has been a rapid growth in the volume of sales of products and services of enterprises operating in the field of information and communication, as well as the share of the industry in Ukraine's GDP. The fastest growing (more than five times over the period under study) is the growth of IT products, in particular the development and implementation of software, consulting in the field of IT technologies and related activities. At the same time, the share of this type of activity in GDP during the study period increased by $3.5 \%$, which indicates a fairly significant innovation shifts in the development of the economy and society. Currently, the IT sector employs almost 180,000 specialists and the number of employees is constantly growing. According to experts, the main factor in the development of the IT industry in Ukraine is a sufficient number of qualified specialists, non-interference of the state in the development of IT business and a favorable taxation mechanism, which allows developing IT in the field of small business and not paying excess profits tax.

Table 1

Dynamics of production volumes of products (services) of the main types of economic activities in the field of digital transformation of the economy in Ukraine

\begin{tabular}{|c|c|c|c|c|c|c|c|}
\hline Types of economic activities & 2013 & 2014 & 2015 & 2016 & 2017 & 2018 & $\begin{array}{c}\text { Growth } 2018 / \\
2013, \% \\
\end{array}$ \\
\hline Telecommunications & 43833.3 & 45927.7 & 48639.7 & 52080.3 & 55775.3 & 64034.8 & 46.1 \\
\hline Specific weight in GDP, $\%$ & 3.0 & 2.9 & 2.4 & 2.2 & 1.9 & 1.8 & -1.2 \\
\hline Computer programming, consulting and related activities & 21432.3 & 32007.4 & 52304.1 & 79149.2 & 107748.4 & 143163.5 & 568.0 \\
\hline Specific weight in GDP, $\%$ & 1.5 & 2.0 & 2.6 & 3.3 & 3.6 & 4.0 & 2.6 \\
\hline Provision of information services & 7381.3 & 8581.7 & 12662.4 & 16753.7 & 23528.6 & 31668.9 & 329.0 \\
\hline Specific weight in GDP, $\%$ & 0.5 & 0.5 & 0.6 & 0.7 & 0.8 & 0.9 & 0.4 \\
\hline
\end{tabular}

Source: calculated by authors based on the data (State Statistics Service of Ukraine, 2020)

As statistics show, in recent years, the volumes of information services have been growing at a fairly rapid pace, in particular in the development of a web portal, cloud computing, and the creation and management of online platforms. During the period 2013-2018, the volume of production of services in this area increased 3 times, and the share in GDP increased by $0.4 \%$. The volume of goods and services production in the field of telecommunications grew at a slightly lower rate $(+46 \%)$ during the period under review, which is explained by the faster rates of development of the industry in 2009-2015, which led to a certain stabilization of domestic demand.

Table 2

Dynamics of financial results of enterprises in the field of information and telecommunications in Ukraine

\begin{tabular}{|c|c|c|c|c|c|c|c|c|c|}
\hline Spheres of digitalization & \multicolumn{3}{|c|}{ Telecommunications } & \multicolumn{3}{|c|}{$\begin{array}{c}\text { Computer programming, consultancy } \\
\text { and related activities }\end{array}$} & \multicolumn{3}{|c|}{ Provision of information services } \\
\hline Years & 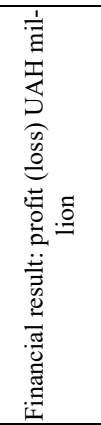 & 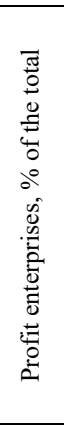 & 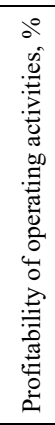 & 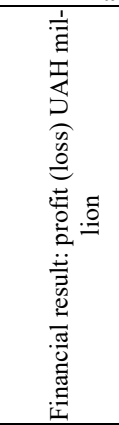 & 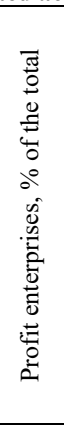 & 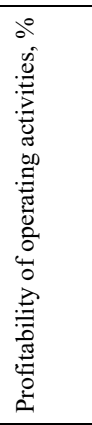 & 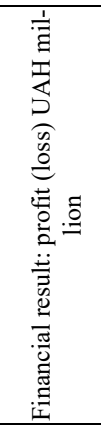 & 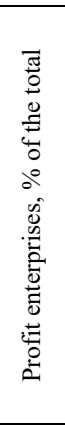 & 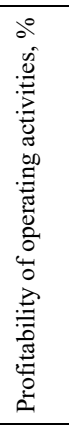 \\
\hline 2010 & 6340.8 & 57.8 & 4 & 397.2 & 57.2 & 3.9 & 263.4 & 58 & 2.2 \\
\hline 2011 & 7581.0 & 61.2 & 5.9 & 646.3 & 65.9 & 3.9 & 342.2 & 62.1 & 4 \\
\hline 2012 & 9368.3 & 63.8 & 5 & 754.1 & 65.8 & 4.3 & 368.6 & 60.2 & 0.7 \\
\hline 2013 & 8678.6 & 64.1 & 3.9 & 1161.6 & 67.3 & 4.8 & 595.1 & 62.5 & 5.5 \\
\hline 2014 & 7991.0 & 64.1 & -4.1 & 2120.2 & 67.2 & 7.2 & 489.7 & 63.2 & 0.6 \\
\hline 2015 & 7548.4 & 71.1 & 1 & 3128.8 & 72.5 & 1.8 & 670.0 & 69.6 & 0.2 \\
\hline 2016 & 7249.2 & 72 & 7.4 & 3484.1 & 70.5 & 7.9 & 716.8 & 65.6 & 2.8 \\
\hline 2017 & 12327.7 & 73.4 & 8.8 & 4224.6 & 70.5 & 7.7 & 1333.4 & 65 & 5.7 \\
\hline 2018 & 12908.6 & 76.3 & 8.1 & 4899.9 & 71.8 & 7.7 & 1600.5 & 66.8 & 4 \\
\hline Growth, 2018/2010\% & 103.6 & 18.5 & 4.1 & 1133.7 & 14.6 & 3.8 & 507.7 & 8.8 & 1.8 \\
\hline
\end{tabular}

Source: calculated by authors based on the data (State Statistics Service of Ukraine, 2020) 
The positive is the growth of value added in the industry at a much faster rate than the volume of services provided, which indicates a significant promising contribution of digital technologies to the development of the national economy. In particular, during the period under review, the gross value added of telecommunications enterprises increased by $155 \%$, information services and IT sphere - by $518 \%$. In addition to the rapidly growing market and relatively high wages, a significant advantage of the information and communications sector is a fairly high level of profitability and profitability in comparison with certain types of economic activity in Ukraine. Table 2 shows the dynamics of the financial results of digital enterprises in Ukraine. As statistics show, the industry is profitable and profitable. At the same time, the gross profit of enterprises is growing at a faster pace, niches are the volumes of product sales, which indicates a high economic potential for the development of the industry and the formation of an internal basis for investment. Over the period 2010-2018, the gross income of IT enterprises (computer programming, consulting and related activities) increased at the highest rates (almost 11 times). Profit in the field of information services during the study period increased by 5 times, and in the field of telecommunications almost 2 times. The share of profitable enterprises on average in the industry is about $72 \%$, which is higher than the industry average. At the same time, there is a tendency to increase the level of profitability of operating activities by an average of $4 \%$ over the past 8 years. These indicators indicate the presence of significant internal economic potential for the development of enterprises in Ukraine, which, when creating a favorable environment, can form the preconditions for a powerful economic leap of the national economy, both by increasing the export of digital technologies and services, and by multiplying the impact on the processes of innovation transformation of other spheres of economic activity of the country. In modern conditions, information technology is becoming one of the most promising areas of investment. According to research by scientists, a $10 \%$ increase in investment in broadband leads to an increase in the average annual GDP, 0.6-0.7\%. Since 2010, the volume of capital investments in the development of the information and telecommunications industry has increased by $246 \%$ and amounted to UAH 29884.9 thousand at the end of 2018. The most rapid growth in capital investment in the industry was observed in 2015 and 2018. At the same time, the share in gross capital investment in the economy during the period under study increased by only $0.4 \%$, except for 2015 , when their share was more than $8.4 \%$. In 2019 , the volume of capital investment in the field of information and telecommunications decreased by $12 \%$ compared to the previous period, and their share in gross investment also decreased by $0.1 \%$. In Fig. 2. shows the volumes and share of capital investments by type of economic activity information and telecommunications in the dynamics of 2010-2018.

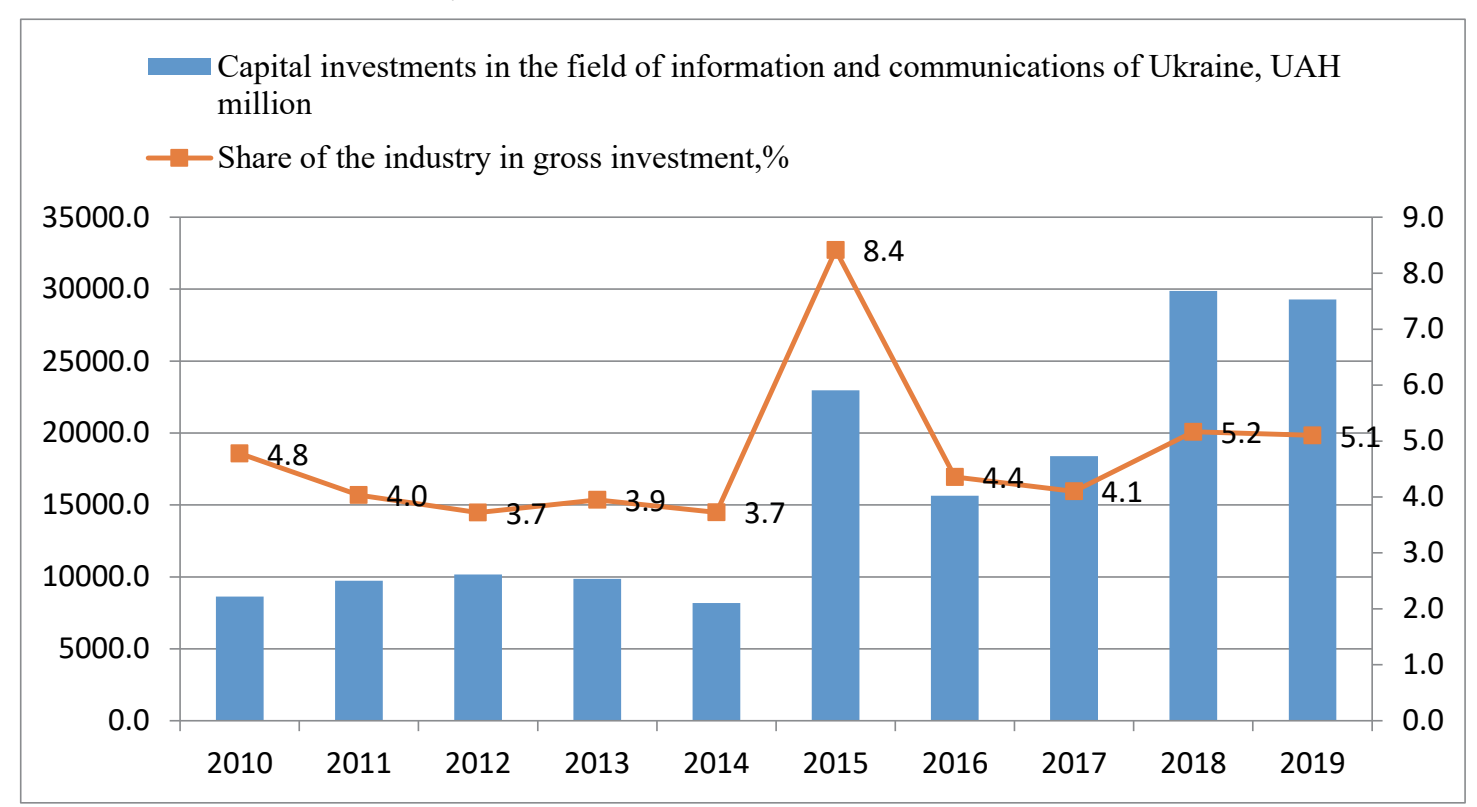

Fig. 2. Dynamics of capital investments in the field of information and communications of Ukraine Source: calculated by authors based on the data (State Statistics Service of Ukraine, 2020)

In terms of the main components of the industry, $11.8 \%$ of investments in 2018 were directed to telecommunications (radio communications), $0.8 \%$ to the computer modelling industry and $1.2 \%$ to the development of information services. This distribution is primarily associated with the level of capital intensity of production of services in the given areas. Against the background of a slight decrease in capital investment in 2019 compared to the previous period, the volume of foreign investment in information and telecommunications in Ukraine is growing. In particular, at the end of 2019, the volume of capital investments amounted to USD 2,9396 million, which accounted for $8.2 \%$ of all foreign investment in Ukraine (Fig. 3.). The largest share of foreign investment is directed to the IT technology sector, due to the orientation of the majority of IT companies in Ukraine and the execution of foreign orders on the terms of outsourcing and export of services. Since 2010, the export volumes of telecommunications, computer and information services have been growing by an average of $7-11 \%$ annually. Wherein the export of IT services is growing rapidly, which during the period under review increased by $174 \%$. The main customers of domestic IT services are US companies (over 60\%), as well as European companies, whose share in the import of information services produced in Ukraine has reached $11 \%$. According to analysts, the volume of export of digital services 
from Ukraine in 2020-2022, provided a favorable climate is created, can grow 3 times and occupy a worthy niche in the export potential of Ukraine. So, the export of IT services from Ukraine has significant potential for development and growth, even in conditions of insufficient government assistance. At the same time, the predominant export orientation of telecommunications products leads to insufficient consumption of IT products in Ukraine. In particular, in 2018, the total volume of ICT services, according to the estimates of the international organization "International Data Corporation", amounted to approximately USD 1.560 billion, which is 6 times less than consumed over the same period by the Polish economy.

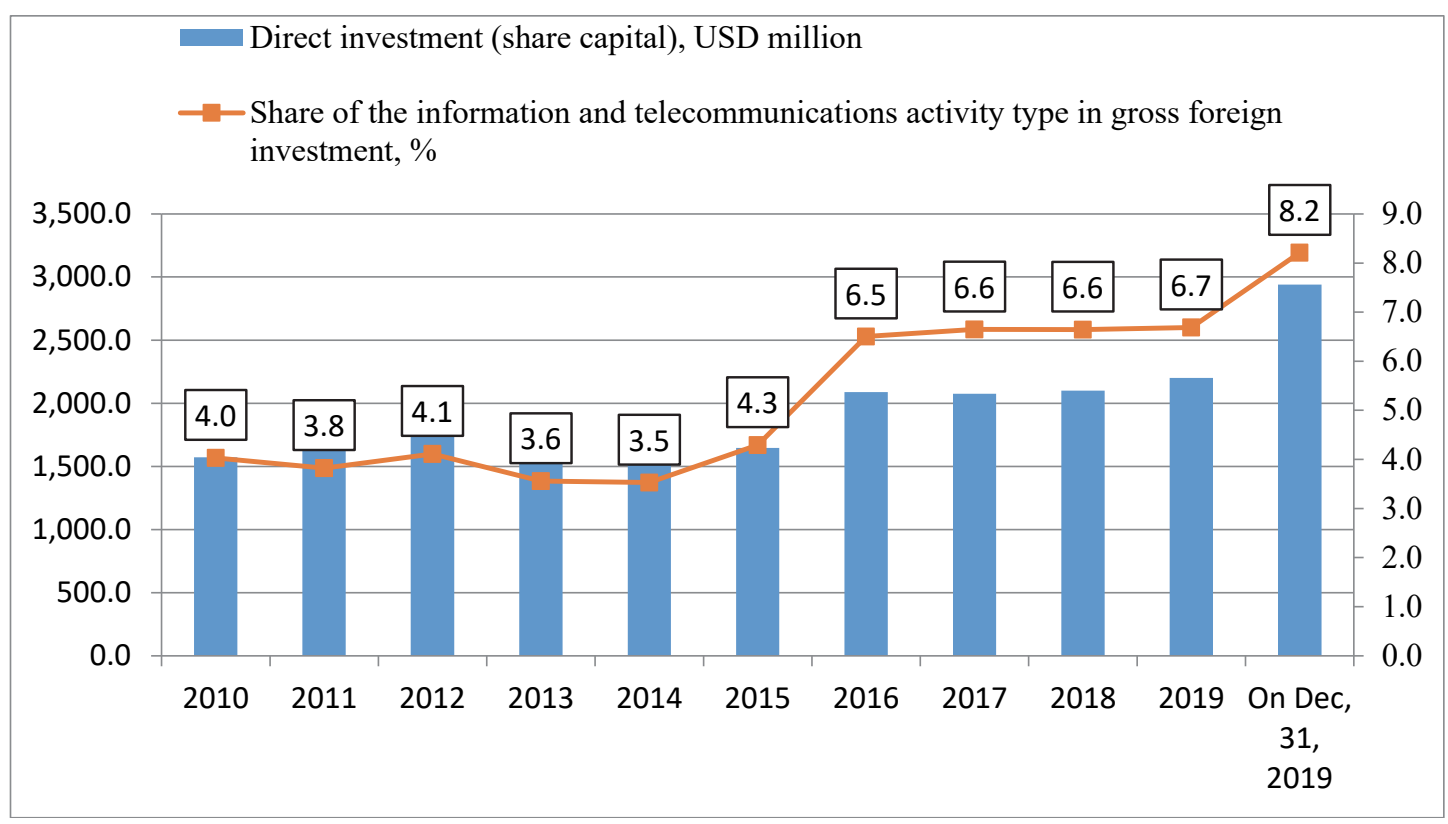

Fig. 3. Dynamics of foreign investment in the development of economic activity type "information and telecommunications" in Ukraine

Source: calculated by authors based on the data (State Statistics Service of Ukraine, 2020)

According to experts from the Ukrainian Institute of the Future, "now there is a significant underfunding of the Ukrainian economy in the context of its technology consumption, that is, the pace and scale of modernization of economic sectors and spheres of life is much lower than that of its neighbours. In total, based on the level of consumption of ICT products and services, one can draw a conclusion about the level of modernization of the country and the level of its productivity and efficiency, which means competitiveness. To achieve a GDP of USD 1 trillion in 2030, the level of consumption of ICT products will significantly increase over the coming years, primarily due to the implementation of large-scale national projects for digital transformations - from priority sectors of the economy to such spheres of life as medicine, education, transport, ecology, tourism, etc." (Ukrainian Institute of the Future, 2020).

In order to accelerate the processes of digital transformation of the economy and society in Ukraine on September 18, 2019, the Ministry of Digital Transformation was created. According to the relevant regulations, the main powers of the ministry include:

- processes of digitalization, digital development, digital economy, digital innovation, e-government and e-democracy, development of the information society;

- promoting the development of digital skills and digital rights of citizens;

- examination of open data, development of national electronic information resources and interoperability, development of infrastructure for broadband Internet access and telecommunications, e-commerce and business;

- provision of electronic and administrative services;

- introduction of electronic trust services for electronic identification and investment in the IT industry;

- promoting the development of the IT industry (Cabinet of Ministers of Ukraine, 2019).

The main objectives of the ministry to be achieved by 2020 are:

- ensuring 100\% access of citizens and businesses to public online services;

- provision of access for more than $95 \%$ of transport infrastructure, settlements and their social institutions to high-speed Internet; 
- level of citizen involvement in digital skills development programs - more than 6 million people;

- growth of the share of IT in Ukraine's GDP up to $10 \%$.

The stated aims are positive and ambitious, but they require the development of clear strategies for their achievement, as well as appropriate legal, administrative and resource support.

We agree with the opinion of Sokolova (2018) that the priority task at the present stage of digitalization of socio-economic systems in Ukraine is "elimination of legislative, institutional, fiscal, tax and other barriers that hinder the development of the digital economy. Another important task is the formation of motivation for the digitalization of society, which consists in ensuring the financial availability of digital technologies for consumers, creating conditions in various spheres of life to form the needs of citizens and businesses to use new digital means instead of the usual, traditional".

Considering the impact of the digital transformation of the economy in the developed countries on GDP as well as the main trends in the development of IT in Ukraine, experts of the "Digital Agenda of Ukraine" initiative have developed a forecast of the possible development of digital transformation of the national economy and society, are shown in Table 3.

Table 3

Forecast indicators of digital transformation of the economy and society in Ukraine

\begin{tabular}{|c|c|c|c|c|c|c|c|c|c|c|}
\hline Indicators & ত্ণ & ָָ & $\stackrel{\text { }}{\widetilde{\gamma}}$ & $\underset{\sim}{\stackrel{\sim}{(~}}$ & 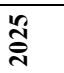 & ֻั & సิ & $\underset{\widetilde{N}}{\stackrel{\infty}{\sigma}}$ & ฮิ & હે \\
\hline Domestic market (ICT consumption), USD billion & 2.0 & 2.5 & 3.0 & 4.5 & 6.0 & 8.0 & 10.0 & 12.0 & 14.0 & 16.0 \\
\hline GDP growth in terms of digital transformation, $\%$ & 0.5 & 1 & 2.0 & 3.5 & 4.5 & 6.0 & 7.5 & 9.0 & 11.0 & 14.0 \\
\hline Share of the digital economy in total GDP, $\%$ & $3 \%$ & $5 \%$ & $8 \%$ & $11 \%$ & $15 \%$ & $20 \%$ & $28 \%$ & $40 \%$ & $52 \%$ & $65 \%$ \\
\hline
\end{tabular}

Source: systematized according (Ucci, 2020)

These forecasts are relative and can be implemented subject to the formation and implementation of a targeted state policy in the field of digitalization, as well as the development of an effective mechanism for its implementation in all areas of management and economic activity. In addition, the forecast was developed in 2016, and at the end of 2018 the cream indicators have already approached the forecast values for 2021. In particular, the domestic ICT consumption market in 2018 reached almost USD 1.6 billion and the share of the digital economy sectors in Ukraine's GDP as of the end of 2018 was more than $4 \%$. Table 4 shows the indicators dynamics of products (services) production and the number of employees employed in the field of digital technologies in the context of the main sectors. These tables show the dynamics of the development of the main spheres of digitalization of the Ukrainian economy in 2010-2018 and the dynamics of GDP in actual prices. As we can see, there are quite negative trends $(-56 \%$ over the period under research) to reduce the number of workers employed in hightech industries for the production of technologies and equipment used in the digitalization of economic and social processes, as well as a relatively insignificant increase in the production of information and communication technologies $(+86 \%)$ compared to other areas of IT. This means that in the face of growing trends in the development of the digital economy of Ukraine, it is becoming increasingly dependent on the import of relevant equipment and technologies.

Table 4

Dynamics of indicators of enterprises development in the digital technologies sector in Ukraine

\begin{tabular}{|c|c|c|c|c|c|c|c|}
\hline Period & 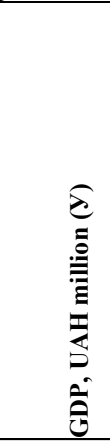 & \multicolumn{2}{|c|}{$\begin{array}{l}\text { Information and com- } \\
\text { munication technologies } \\
\text { in production (B) } \\
\text { is }\end{array}$} & 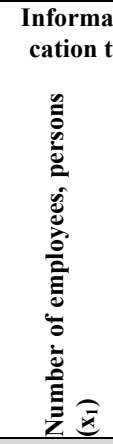 & $\begin{array}{l}\text { and communi- } \\
\text { nologies in ser- } \\
\text { es }(P)\end{array}$ & 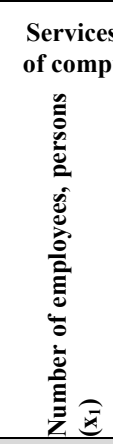 & 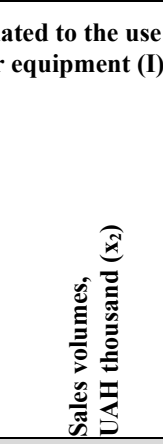 \\
\hline 2010 & 1079346 & 23718 & 4611.112 & 174832 & 58367.723 & 37921 & 8339.950 \\
\hline 2011 & 1299991 & 28425 & 9382.276 & 172432 & 66120.698 & 43760 & 11509.300 \\
\hline 2012 & 1404669 & 18739 & 5388.037 & 172142 & 80526.051 & 48916 & 16324.425 \\
\hline 2013 & 1465198 & 16760 & 5063.316 & 172133 & 83386.604 & 53664 & 19538.380 \\
\hline 2014 & 1586915 & 11623 & 5082.242 & 152353 & 92636.029 & 47735 & 24080.244 \\
\hline 2015 & 1988544 & 10337 & 4538.955 & 130348 & 113287.132 & 45257 & 37534.857 \\
\hline 2016 & 2385367 & 11004 & 6349.731 & 121154 & 144332.172 & 44939 & 48660.282 \\
\hline 2017 & 2983882 & 10670 & 6637.844 & 118303 & 181404.689 & 47177 & 60826.902 \\
\hline 2018 & 3560596 & 10341 & 8588.477 & 117600 & 222233.103 & 49533 & 76545.025 \\
\hline Growth, \% & 230 & -56 & 86 & -33 & 281 & 31 & 818 \\
\hline
\end{tabular}

Source: calculated by authors based on the data (State Statistics Service of Ukraine, 2020) 
The greatest growth during 2010-2018 is observed in the information sector, that is, the sector of services related to the use of computer equipment. During the research period, the number of people employed in this sector increased by $31 \%$, and the volume of services provided by $818 \%$, that is, more than 8 times.

An important element in the formation of state and regional policy in the field of digitalization is forecasting the development of the main sectors of the information and communication sphere and their impact on economic growth. We have reviewed the forecasts of specialists in the main areas of digital transformation in Ukraine. However, we consider it appropriate to carry out a correlation and regression analysis of the impact of the development of individual sectors of the information and communication sphere on GDP, the results of which can be useful for adjusting tactical plans for implementing the digital transformation strategy by stimulating the development of certain types of economic activity.

Using the data in Table 4 and the corresponding functions of mathematical programs, regression models of the influence of individual sectors of the digital technologies sphere on Ukraine's GDP were built and verified. The results of the calculations are shown in Table 5.

Based on the results of the calculations, it was determined that there is no linear relationship between the sector of production of information and communication technologies and GDP. This is evidenced, in particular, by the obtained coefficient of determination $\mathrm{R}^{2}=0,18$. That is, during 2010-2018, the industry for the production of high technologies and equipment for the digitalization of the economy developed mainly in the context of outsourcing and international cooperation and did not have a significant impact on the formation of GDP. This has led to the fact that Ukraine is significantly dependent on the import of relevant equipment and technologies, constitutes significant obstacles to the active introduction of digital technologies in all spheres of life.

Table 5

Correlation-regression analysis of the main indicators impact of the digital technologies' development on the GDP of Ukraine

\begin{tabular}{|c|c|c|c|}
\hline \multirow[b]{2}{*}{ Indicators } & \multicolumn{3}{|c|}{ Production volumes of products (works, services), UAH million } \\
\hline & $\begin{array}{c}\text { Information and commu- } \\
\text { nication technologies in } \\
\text { production }\left(\mathrm{x}_{1}\right)\end{array}$ & $\begin{array}{c}\text { Information and communi- } \\
\text { cation technologies in ser- } \\
\text { vices }\left(\mathrm{x}_{2}\right)\end{array}$ & $\begin{array}{l}\text { Services related to the use } \\
\text { of computer equipment } \\
\left(x_{3}\right)\end{array}$ \\
\hline Regression equation & $y=707654.6+0.20 x_{1}$ & $y=228758.6+0.016 x_{2}$ & $y=0.14 x_{3}-687753.4$ \\
\hline Coefficient of determination $\left(\mathrm{R}^{2}\right)$ & 0.18 & 0.99 & 0.69 \\
\hline \multirow{2}{*}{$\begin{array}{l}\text { Checking the equation significance } \\
\text { F calc. }>\text { Ftab. }(a=0.05)\end{array}$} & 1.54 & 2939.2 & 6.99 \\
\hline & 0.82 & 0.82 & 0.82 \\
\hline Coefficient of elasticity, $\%$ & - & 0.093 & 0.0013 \\
\hline
\end{tabular}

Source: calculated by the authors

The models were verified according to Fisher's F-test and showed that all three models are statistically significant.

The analysis showed that the sectors for the production of information and communication services $\left(\mathrm{R}^{2}=0.99\right)$ and services related to the use of computer equipment $\left(\mathrm{R}^{2}=0.69\right)$ have a significant impact on the development of the national economy, in particular, GDP. In particular, an increase in the volume of services and work in the field of information and telecommunications by UAH 1 million all other things being equal, leads to an increase in GDP by UAH 16 thousand, and an increase in the volume of digital services in the economy by UAH 1 million - to increase the GDP by UAH 140 thousand. This indicates a fairly wide, but insufficient (in comparison with developed countries) penetration of digital technologies into the production of added value in the Ukrainian economy. The extrapolation growth in the production of goods (services) in the information sector for the period up to 2023 is shown in Fig. 4. The calculations showed that, provided that the previous trends continue, the production of services using computer technologies for the period from 2018 to 2023 will grow by $25 \%$. In 2020 , a certain "subsidence" of the market is possible, but already in 2021 there will be an accelerated growth of $11.4 \%$.

Using formula 1, the forecast values of GDP were calculated under the influence of trends in the development of information technologies. According to the results of forecasting the development of the information services sector using computer technologies, it was found that with the growth of this sector in the forecast period (2019-2023) by $25 \%$, GDP growth will be $47.3 \%$ with $45.6 \%$ of the forecast growth, excluding the impact of this sectors (Fig. 5).

Consequently, while maintaining the existing trends and the constant impact of external factors, the increase in the volume of information services using computer equipment (that is, directly the digitalization processes) by 2023 will be $25 \%$, which, starting from 2022, will have a fairly significant impact on GDP growth. This is primarily due to the activation of informatization processes in all spheres of production, management, market and social activities, an essential part of which is the development of electronic marketing and commerce. 


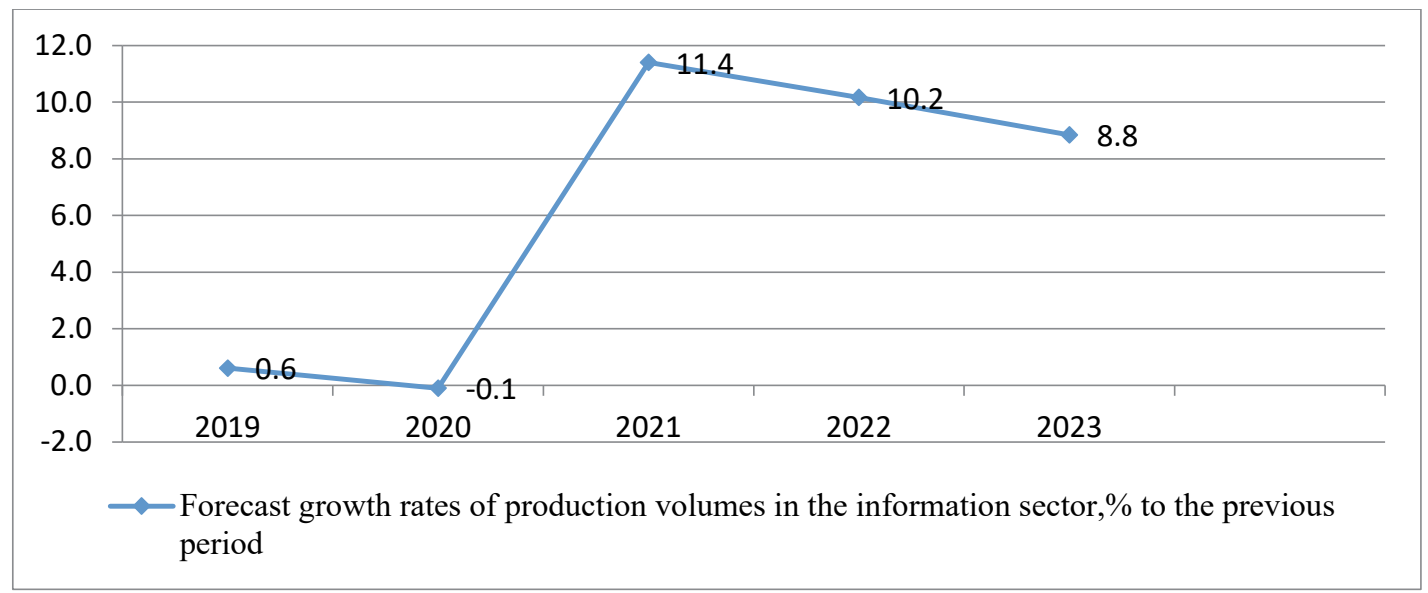

Fig. 4. Forecast extrapolation trend of production (services) growth in the information sector of Ukraine Source: calculated by the authors

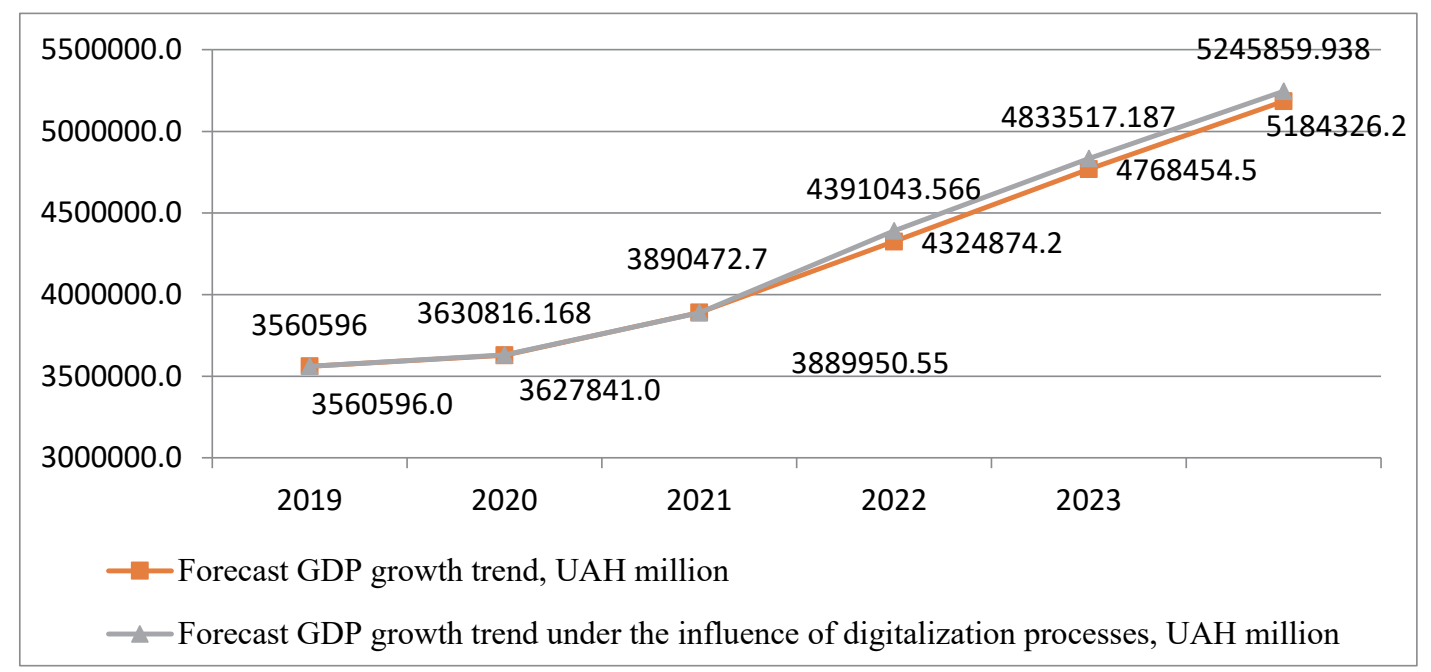

Fig. 5. Forecast of Ukraine's GDP growth taking into account the processes of the economy digitalization in accordance with certain trends

Source: calculated by the authors

The projected extrapolation growth in the production of IT services for the period 2018-2023 with a stable influence of existing and the absence of new stimulating factors or where stimulating factors will be $148.9 \%$. Forecast extrapolation dynamics of the IT market development in 2019-2023 is shown in Fig. 6.

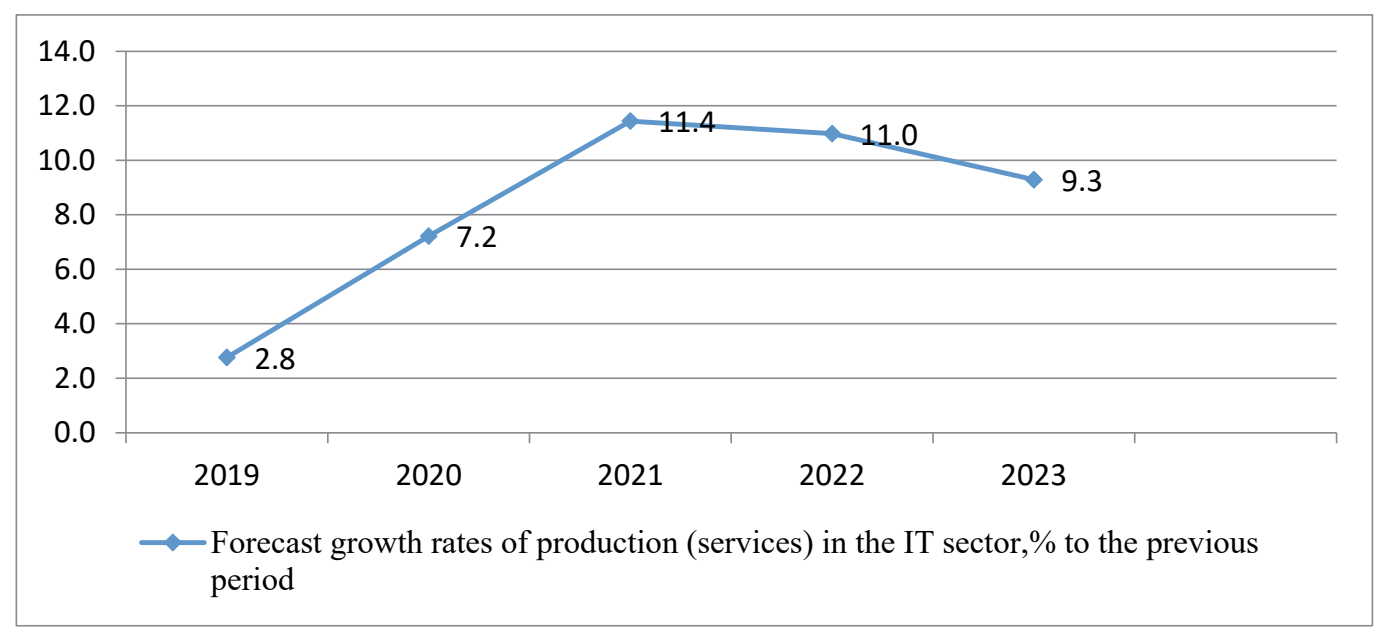

Fig. 6. Forecast extrapolation trend of production (services) growth in the IT sector of Ukraine Source: calculated by the authors 
Calculations carried out using formula 1 showed that despite the significant growth of the IT market until 2023 (taking into account past trends), its impact on GDP is lower than in developed countries, that is, it will lead to its GDP growth by only $5.7 \%$ compared to general forecast GDP trend. This situation is primarily associated with an insufficient level of consumption of IT services in the Ukrainian economy in the past. Fig. 7 illustrates the forecast dynamics of GDP changes under the influence of the development of the IT sector until 2023.

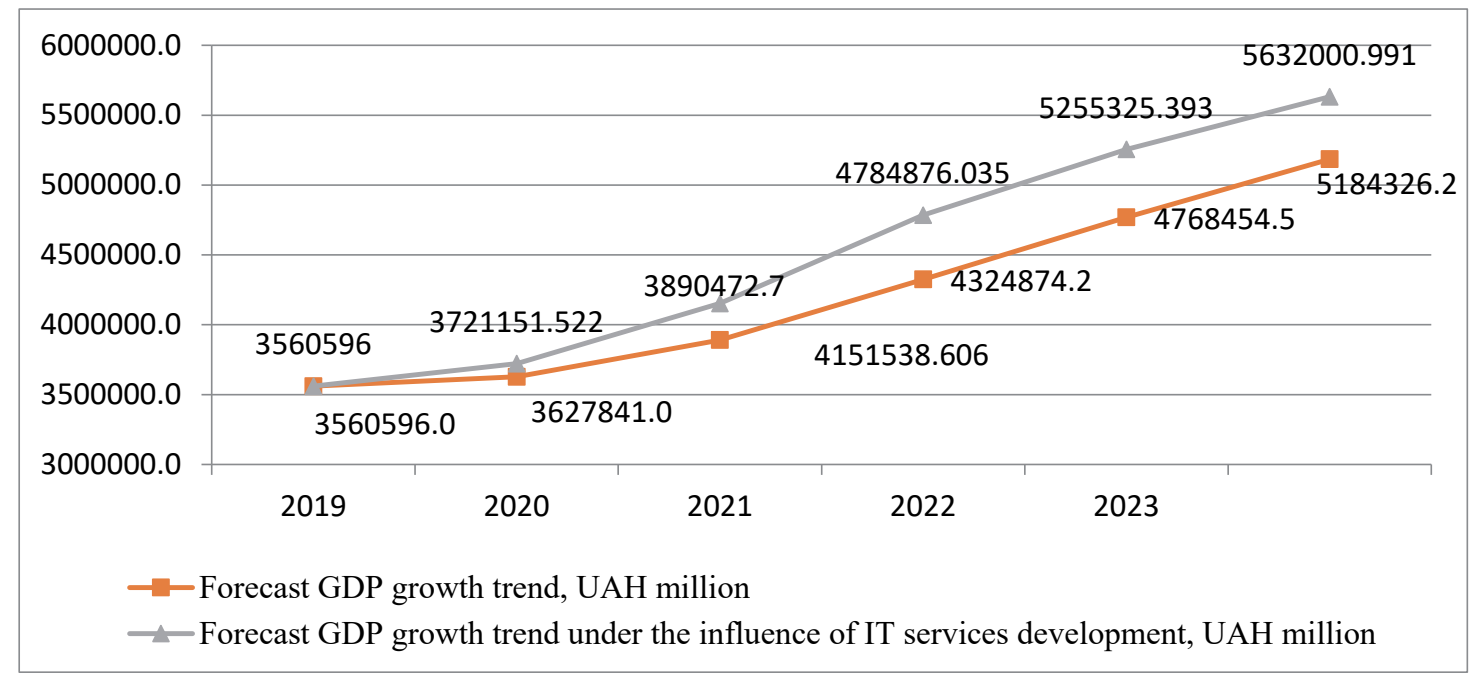

Fig. 7. Forecast of Ukraine's GDP growth under the influence of the IT sector development in accordance with certain trends Source: calculated by the authors

Thus, the results of modelling the impact of the digital technologies development on economic growth demonstrate the possibility of ensuring the acceleration of the growth rate of Ukraine's GDP under the influence of the IT sector development in accordance with certain trends.

\section{Conclusion}

In general, predicting the impact of digitalization on the economy development of Ukraine and its regions using extrapolative trends is not correct enough, since digital technologies in various areas of operation do not spread linearly and at different rates, and also have an impact not only on the development of specific industries or territories, but also on related economic activities and processes of social transformation. However, the use of the calculations and models carried out will make it possible to model the influence of individual factors of state stimulation of the development of sectors and industries on the development of economic and social processes. In addition, the use of the proposed approaches to modelling the impact of digital technologies development on economic growth makes it possible, at the regional and individual territorial level, to improve the process of developing regional digital transformation programs for the main implementation of mechanisms to eliminate the digital divide between territories, types of economic activity and social institutions.

The analysis of the impact of the digital technologies development on economic growth also showed that, despite a sufficiently powerful scientific base and human potential, Ukraine lags significantly behind most developed countries in terms of the development level of industrial production in information and communication technologies and equipment as well as is completely import-dependent in this area. Negative trends $(-56 \%$ over the period under research) were revealed in the reduction of the workers number employed in knowledge-intensive industries for the production of technologies and equipment used in the field of economic and social digitalization processes, as well as a relatively insignificant increase in the production of information and communication technologies $(+86 \%)$ in comparison with other IT spheres, means that in the conditions of growing trends in the digital economy development of Ukraine, it is becoming more and more dependent on the import of relevant equipment and technologies. Stimulating the development of industrial production of information and communication technologies has significant prospects for enhancing the processes of digitalization in all spheres of the economy and society and increasing GDP.

\section{References}

Association of Retailers of Ukraine (2020). Dynamics of e-commerce market development. Retrieved July, 19, 2020 from: https://rau.ua

Cabinet of Ministers of Ukraine. (2019). Regulations on the Ministry of Digital Transformation of Ukraine. Retrieved July, 11, 2020 from: https://zakon.rada.gov.ua/laws/show/856-2019-\%D0\%BF

Fuchs, C. (2008). The implications of new information and communication technologies for sustainability. Environ DevSustain, 10, 291-309.

Irtyshcheva, I., Kramarenko, I., Shults, S., Boiko, Y., Blishchuk, K., Hryshyna, N., ... \& Krapyvina, D. (2020). Building favorable investment climate for economic development. Accounting, 6(5), 773-780. 
Hlinenko, L. K., \& Daynovskyy, Y. A. (2018). State-of art and prospects of development of Ukrainian electronic commerce. Marketing and Management of Innovations, 1, 83-102. http://doi.org/10.21272/mmi.2018.1-06

Kit, L.Z. (2014). Evolution of network economy. Visnyk of Khmelnytsky National University. Economic sciences, 3(2), 187194.

Maksymiv, Y.V. (2016). Reporting as an important tool in ensuring interaction between stakeholders. Actual Problems of Economics, 178(4), 304-310.

Malyk, I.P. (2013). Tendencies of information economy development in Ukraine. Bulletin of the Eastern European University of Economics and Management, 1(14), 25-34.

Melnyk, M., Korcelli-Olejniczak, E., Chorna, N., \& Popadynets, N. (2018). Development of Regional IT clusters in Ukraine: institutional and investment dimensions. Economic Annals-XXI, 173(9-10), 19-25. https://doi.org/10.21003/ea.V173-03

Mulgan, G. (1991). Communication and Control: Networks and the New Economies of Communication, Polity, Cambridge, UK.

NVBusiness. (2020). Online sales, TV viewing growth and contactless delivery. How coronavirus has affected business and consumption - research. Retrieved Mau, 21, 2020 from: https://nv.ua/ukr/biz/markets/pandemiya-koronavirusa-shchozminilosya-dlya-biznesu-i-spozhivachiv-novini-svitu-50077243.html

Park, S.-C. (2018). The Fourth Industrial Revolution and implications for innovative cluster policies. AI \& Society, 33(3). https://doi.org/10.1007/s00146-017-0777-

Pavlova, O., Pavlov, K., Novosad, O., Irtyshcheva, I., Popadynets, N., Hryhoruk, I., ... \& Boiko, Y. (2020, September). Strategic Priorities for Socio-economic Development of Ukraine in Comparison with the Republic of Poland. In International Conference on Human Systems Engineering and Design: Future Trends and Applications (pp. 308-314). Springer, Cham. https://doi.org/10.1007/978-3-030-58282-1_49

Pryshchepa, O., Kardash, O., Yakymchuk, A., Shvec, M., Pavlov, K., Pavlova, O., ... \& Kramarenko, I. (2020). Optimization of multi-channel queuing systems with a single retail attempt: Economic approach. Decision Science Letters, 9(4), 559564.

Semjachkov, K. A. (2017). The digital economy and its role in the management of modern socioeconomic relations. Modern Management Technology, 8 (80). Retrieved Mau, 26, 2020 from: http://sovman.ru/article/8001/

Sokolova, H.B. (2018). Some aspects of the development of the digital economy in Ukraine. Economic Bulletin of Donbass, $1(51), 92-96$.

State Statistical Service of Ukraine. (2020). Statistical Yearbook of Ukraine. Retrieved July, 09, 2020 from: http://www.ukrstat.gov.ua

Stroyko, T., Irtyshcheva, I., \& Stehney, M. (2013) Public regulation of integration systems development in agri-food sphere of Ukraine under globalization. Actual Problems of Economics, 3,125-134.

Tapscott, D. (1996). The Digital Economy. McGraw-Hill.

Ucci. (2020). Digital Agenda of Ukraine - 2020. Project. Retrieved March, 29, 2020 from: https://ucci.org.ua/uploads/files/58e78ee3c3922.pdf

Ukrainian Institute of the Future. (2020). Ukraine 2030E is a country with a developed digital economy. Retrieved July, 21, 2020 from: https://strategy.uifuture.org/kraina-z-rozvinutoyu-cifrovoyu-ekonomikoyu.html\#6-2-1

Vasyltsiv, T., Irtyshcheva, I., Lupak, R., Popadynets, N., Shyshkova, Y., Boiko, Y., \& Ishchenko, O. (2020). Economy’s Innovative Technological Competitiveness: Decomposition, Methodics of Analysis and Priorities of Public Policy. Management Science Letters, 10(13), 3173-3182. doi: 10.5267/j.msl.2020.5.004

Voynarenko, M.P., \& Skorobohata, L.V. (2015). Network tools for capitalization of information-intellectual potential and innovations. Visnyk of Khmelnytsky National University. Economic sciences. 3(3), 18-24.

Yakubiv, V. M. (2015). Accounting and analytical methods of diagnostics improvement for enterprises' organizational development. Economic Annals-XXI, 3-4(1), 68-71.

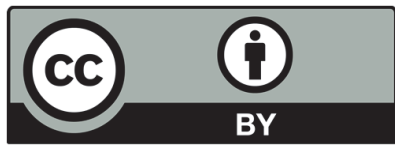

(C) 2021 by the authors; licensee Growing Science, Canada. This is an open access article distributed under the terms and conditions of the Creative Commons Attribution (CC-BY) license (http://creativecommons.org/licenses/by/4.0/). 